\title{
Second Language Interference towards First Language Use of Japanese Learners
}

\author{
Zulfadli A. Aziz \\ Universitas Syiah Kuala, Banda Aceh Indonesia \\ Correspondingemail:zulfadli.aziz@unsyiah.ac.id
}

\section{Bukhari Daud}

Universitas Syiah Kuala, Banda Aceh Indonesia

bukhari_daud@yahoo.co.id

\author{
Syafira Yunidar \\ Universitas Syiah Kuala, Banda Aceh Indonesia \\ sy.yunidar@gmail.com
}

\begin{abstract}
:
There have been many studies on first language interference towards learners' second or foreign language learning, but not many on the otherwise. This study investigates the effects of learning Japanese as a foreign language towards learners' first language use, Indonesian. The data for this qualitative study were obtained from five Japanese learners who had different backgrounds of Japanese learning. Observation and interview were used as the research instruments to collect the data in this study. The results were found that the learners showed foreign language effects; grammatical aspects and borrowing. In short, learning a foreign language (FL) influences learners' first language (L1), which means that learning Japanese language had affected the learners' first language, Indonesian. It can be concluded that learning a second or foreign language may interfere a learner's first language.
\end{abstract}

Keywords: first language, L1, foreign language, FL, Indonesian, Japanese

\section{Introduction}

The main goal of learning a foreign language is to be able to speak that language (Grauberg, 1997, p. 201; East, 2016, p. 118). Flohr and Paesler (2010, p. 6) state that speaking is the most important skill in learning a foreign language and the goal is to become a fluent speaker. When learners can use and communicate in a foreign language well, they get used to speaking in the 
language. As a result, the learners' first language (L1) will be affected by their foreign language (FL) (see Pavlenko, 2000; Jarvis, 2003; Noor, 2007). The influence may occur in some aspects such as pronunciation and intonation, word choice, and sentence structure patterns. When the fluent foreign language learners speak their first language, such foreign language aspects will usually be noticed.

When learners speak in a foreign language, they should choose proper words to convey the true meaning to avoid misunderstanding. Sometimes some equivalent words or expressions cannot be found in their first language. It, therefore, leads learners to do borrowing transfer which is one of effect showed by a foreign language learner, and it refers to an addition of foreign language elements to speakers' first language (Pavlenko, 2003, p. 33). Borrowing transfer means the influence a foreign language has on a previously acquired language (which is typically one's native language) (Odlin, 1989, p. 12).

Learning the second language (L2) could influence the learners' first language (L1) in diverse areas such as phonology, morphosyntax, or semantics system (Pavlenko, 2000). Language learners may not be aware that their L2 will influence on their L1. Bilingual or multilingual speakers may do transfer, phonological change and other possible acts influenced by their L2 on L1. These phenomena often happen when they speak. It is clear that their second language(s) will affect their first language (see Kecskes, 2008; Wang, 2014). Those influences should affect the way they speak in their first language.

L2 may affect on L1 in the forms of borrowing transfer, convergence, shift, restructuring transfer, and L1 attrition (Pavlenko, 2003). These five phenomena give significant contribution to the second language influences on first language. Wang (2014, p.728) has found that the FL learners' proficiency would affects their L1 when the learners do transfer. Some other researchers believe that L2 will affect L1 even though not all L1 aspects are influenced by L2 (see for examples, Kaushanskaya, Yoo\& Marian, 2011; Jarvis, 2003; Harada, 2003). Therefore, we do not put aside the effect of L2 on L1.

It is of course no doubt that learning L2 may give positive effect to the learners (Bournot-Trires \&Tellowitz, 2002). At the same time learning a foreign language will affect their first language. Pavlenko (2000) says that L2 influence on L1 phonology in adulthood in alphabetical order and with regard to the key variables such as language involved, subjects' ages at the time of study, age of acquisition, length of exposure, context of acquisition, and L2 effects. Based on the phenomena described above, this present study investigates the effects of Foreign Language (FL) learning on the learners' L1 use.

\section{Literature Review}

First language is defined as innate language that people are exposed to from birth (Bloomfield, 1983; Harley et al, 1990; Chomsky, 2000; Gera, 2003). When people learn their first language, they do not need to give great effort to learn it (Harley et al, 1990). Children are not born talking, they should learn the language step by step controlled by adult (Clark, 2003). For Gass and Selinker (2001), L1 refers to the first language that people learn. People acquire their first language during the first year of life (Ingram, 1989). Ingram (1989) provides some factors that 
need to be considered when people learn the language; 1) there is the issue of comprehension vs. production; 2) we need to decide between adult and non-adult vocalizations as in definition (any vocalization of the child that is used in a consistent context); 3) there is the issue of correct pronunciation.

A first language is a mother tongue or a native language and it is used in a society as a communication tool. Widely varying definitions of first language have emerged (Gass \& Selinker, 2001). Gass and Selinker (2001) define Native Language (NL) as the first language learned by people. In other words, L1 refers to learners' NL which has been learned since they were children. This language is also known as the primary language, the mother tongue or the L1 (first language).

The first language will be used solely when referring to first language acquisition. The term commonly refers to the natural development of language which takes place in childhood, from birth (Cruz-Ferreira, 2011). The mother tongue, the native language, and the primary language emerge as reliable definition of first language. People learn their first language by acquiring the language step by step from the early stage of their life.

Foreign language (FL) is different from second language (L2). People argue about the difference because of the two important factors, those are, sociocultural environment of the acquisition process and the linguistic background of the learners (Kecskes\& Papp, 2000). Foreign language is a language spoken by nonnative speakers. It refers to a foreign language that we learn in our native country. Foreign language learning is the learning of a nonnative language in the environment of one's native language (Gass\&Selinker, 2001), such as Indonesian speakers learn Japanese language in Indonesia.

In learning a foreign language, learners may establish an error as a sign of failure. However, a new word learned could encourage learners to construct rules in the target language's structure. In other words, the errors made by the learners cannot be seen as failure in learning a foreign language (Littlewood, 1984). Pienemann (1980), cited in Littlewood (1984) found that learners did not master an individual rule suddenly, with an abrupt change from using it always wrongly in one interview to use it always correctly in the next.

\subsection{The Effect of Foreign Language Learning on First Language (L1)}

Many researchers have found that first language might affect second/foreign language learning (see for example, Harley et al, 1990; Kecskes 2008). L1 effects could be negative and positive. Kecskes (2008) states that the L1 effects on L2/FL learning give negative impacts on language's grammatical, lexical and/or phonological errors. However, L1 habits also give positive transfer in acquiring foreign language habits (see Littlewood, 1984; Hakuta 1993).

It is not only L1 which influences FL learning (see for example, Pavlenko, 2000; Jarvis, 2003; Noor, 2007; Kecskes, 2008; Wang, 2014). There are many effects that occur when we learn foreign language on our first language. It could be in the areas of bilingual lexicon and phonology (Pavlenko, 2000, p. 179). Pavlenko (2003, p. 33)also argues that FL influences appear 
in five phenomena, namely, borrowing transfer; convergence; shift; restructuring transfer; and L1 attrition.

First, borrowing transfer is referred to the addition of FL element in L1 (Pavlenko, 2003). Borrowing transfer may affect learners' phonology and phonetics (Odlin, 1989). This phenomenon may happen as communicative strategy. The process is involved when a speaker uses some terms in foreign language into first language to adjust the meaning of the words that sometimes cannot be translated into the L1. Language learners do switching in order to avoid misunderstanding because there is no word in their L1 that is suitable to be interpreted. Moreover, when it is translated, the meaning becomes odd or funny. For example, lexical borrowing such as the terms bid ('bid') or bebisitter ('babysitter') in the speech of Russian immigrants in the US, documented in Andrews (1999) (Pavlenko, 2003). Another example that the researcher experienced is when the Japanese language learners say -san pronunciation [san] however the sound is closed to [san]. This is an honorific word put after someone's name.

Second, convergence refers to the creation of a unitary system, distinct from both L1 and L2, e.g. the use of the same phonetic realization rules (Pavlenko, 2003, pg. 33). Convergence varieties will highly occur throughout bilingual communities (Braunmüller \& House, 2009). They usually differ between FL phonology and L1 phonology even though they have the same phoneme. For example, the use of the same phonetic realization rules for French and English $/ t /$, which results in a moderately aspirated stop, different from both L1 and L2 values, documented by Flege (1987) in the speech of late French/English bilinguals;

Third, language shift refers to language changes caused by situation faced by speakers. Batibo (2005) explains that language shift is occurred when speakers abandon their language, willingly or under pressure, in favor of another language, which then takes over as their means of communication and socialization. People who live in bilingual or multilingual region have bigger chance to go through language shift. Likely, they change the language to communicate in accordance with the situation and their interlocutor. Language shift is the replacement of one language by another as the primary means of communication and socialization within a community (Potowski, 2013). However, that change is not only on their own, but also may be other factors causing them change their language into another.

Fourth is restructuring transfer. Language transfer occurs when someone learns a new language, however, when he/she has already learnt the FL, it absolutely will affect his/her L1, especially in his/her phonological area. Dickerson (1975), cited in Corder (1993), argues that the pronunciation of a second language is indeed largely a matter of progressively restructuring the mother tongue phonological system in the direction of the target language. Pavlenko (2003) says that restructuring transfer refers to incorporation of FL elements into L1 resulting is some changes, substitutions or simplifications.

Finally, L1 attrition is described as some elements of L1 which are loss(or inability to produce) caused by foreign language influence (Pavlenko, 2003). The researcher will see whether the learners are able to produce L1 structurally correct, otherwise the FL affects them in this module 
of grammar.L1 attrition may be caused by external factors in sociolinguistics perspective, such as age, level of education, and frequency of speech community (Montrul, 2008).

Besides the foreign language learning effects found by Pavlenko (2003) above, other FL influences have also suggested by other researchers. Wang (2014) and Cook (2003) suggest that the foreign language can affect the first language in at least three ways: it enhances the use of the first language; it harms the use of the first language or it is neutral to the use of the first language.

The first is the use of the L1 will be enhanced. Bilingual people will speak or write in different ways compared to monolingual people. They sometimes use more complex sentences in their first language (Kecskes \& Papp, 2000). Bilinguals and monolinguals do not show significant different toward their knowledge about language, however, the bilingual people show metalinguistic awareness (Bialystok, 1991; Bialystok, 2001; Murphy \& Pine, 2003). Yelland et al. (1993) state that learning foreign language an hour a week does not enough to make learners produce great effect of FL. They observed for English-spoken children who studied Italian one hour each week and the result, the learners showed better on their English.

The second, it harms the use of the L1. The effects of FL on L1 such as language loss or attrition may happen. Cook (2003) argues that:

“.... context for discussing possible harmful effects of the FL on theL1 is language loss or attrition. .... As a person gains the ability to use a foreign language, so he or she may to some extent lose the ability to use the first language. In circumstances where one language becomes less and less used, people do lose their command of it, whether as a group or as individuals. ....."

The last is the L1 is different from the FL, without being better or worse (Cook, 2003). Some studies conducted about the effect of FL may be hard to regard as either positive or negative. For example Jarvis (2003) finds about the FL (English) effect on L1 (Finnish) in case of a Finn seem neither good nor bad. Similarly, the study conducted by Cenoz (2003) with Spanish learners of English indicates that subjects do not denote differences when they conceive the requests in English and Spanish.

Another effect that commonly occurs is grammatical error. Kecskes (2003) states that FL learning will affectL1 structure grammatically based on the language and cultural distances. He explains the distances go together with culture influenced by geographical distance. In other words, learners should learn the foreign language culture to be able to speak and to avoid misunderstanding. It might unconsciously affect learners' L1 grammar.

As a result of different structure and pattern between one language and the other, learners may be interfered by each other of the language. For example, Japanese is a subject-object-verb language which is very different to Indonesian which has a subject-verb-object. In a Japanese sentence, verb is very important. It plays a main rule in a sentence, therefore subjects and objects can be omitted. A sentence needs a verb, but it does not need a subject or object at all to form a correct minimal sentence in Japanese (Kamermans, 2010). For example, in Indonesian, we will say saya makan nasi (I eat rice) which is an SVO. It requires the subject to complete a sentence. While in Japanese, the subject can be omitted ご飯を食べます(gohanwotabemasu) which mean saya makan nasi. 


\subsection{Factors FL Learning Affecting the Learners' L1}

The main factors affecting the language learners are the learners' characteristics and environment (Lightbown \& Spada, 2013). The adult learners have metalinguistic awareness when they learn an FL. Metalinguistic awareness is the developmental stage of the ability of the child to focus on complex aspects of language structure (Yelland et al., 1993). On the other hand, this cognitive awareness makes the learner avoid mistakes when they speak FL, however it makes them stressful if they cannot express what they want to speak about correctly.

The learners' experience will affect their FL learning. Moyer (2004) states that the learners' experiences are based on three contexts; first, they learn the language as bilingual program, second, they learn the language as foreign language, third is in immersion context. Those experiences indeed influence the learners' FL learning. Learners who have acquired general knowledge and experience are better to develop a new language than that those who have not. When a learner, for example, experiences in learning Japanese in its native country he/she will determinately affect his/her Japanese, either the learner who is studying intensively both with friends and teacher as well as his/herself.

\subsection{Language Interference}

Language interference means the realignment of a language system that result from the introduction of foreign elements into the more highly structured domains of language (Weinreich, 1968). The term of interference is also known as transfer, L1 interference, linguistic interference, and cross meaning (see for example, Peukert, 2015;Odlin, 2013; Weinreich, 1968).

Dulay et al. (1982, p. 101) argue that these are two types of transfers; positive transfer and negative transfer. Positive transfer is the correct utterance, because both the first language and second language have the same structure. On the contrary, negative transfer refers to an error because of the old habitual behavior which is different from the new behavior being learned. Positive transfer was predicted to occur when patterns are similar in the L1 and the FL, which result in a correct utterance, while negative transfer would occur when patterns are different, causing errors in language production. Otherwise interference is known as negative effect of transfer (Callies, 2015, p. 130). In other words, the negative transfer from the native language is called interference.

Interference is the deviation of target language as a result of their familiarity with more than one language. Dulay et al. (1982) explain that interference is differentiated into psychological and sociolinguistic. Psychological use the term interference refers to learners' habit when they learn something new. While in sociolinguistics, interference refers to language interaction, such as linguistic borrowing and language switching. According to Lott (1983, p. 256) interference is defined as errors in the learners' use of the foreign language that can be traced back to the mother tongue. For example, Indonesian sentence structure always requires subject, but in Japanese, subject can be omitted. Such as in a sentence, saya berasal dari Jepang 'I come from Japan’ - Nihonkara kimashita (日本から来ました). The learners will say watashiha Nihonkara kimashita (私は日本から来ました). They usually put saya 'I' in the first 
sentence. New Japanese language learners' use such complete sentences while it is not required in the Japanese language.

However, as explained above, foreign language learners bring their L1 aspect on the FL they learn. It occurs because of the habit in their L1. In contrary, that habit could disappear when FL affects their L1 caused by factors mentioned before. When the learners start learning Japanese, they will find that the alphabet have different sound from Indonesian, especially tsu (つ), they will say tsu like tsuin Arabic. When an understanding of one language influences on the understanding of another language, it means that the learners are experiencing language transfer (Ellis, 1997, p. 51).

Positive L1-transfer was taken to mean that the first language had a facilitating effect on L2learning, whereas negative transfer, or interference, caused errors in the learner's production (Ringbom, 1987, p. 58).In positive transfer, the learners will relate the FL words on L1 words which have similar pronunciation or closed to the pronunciation so that the learners quickly remember the vocabulary. For example, suki (好き) - suka, mata (また) - sampaijumpa, kakimasu (書きます) - menulis, nana (七) - tujuh, etc.

Language interference is the effect of language learners' first language on their production of the language they learn, or the learners' first language influences their second or and their foreign language. The effect can be in any aspects of language, such as grammar, vocabulary, accent, spelling and so on.

Corder (1981) states that interference can be mentioned as a learner's strategy. He suggests that the learners' L1 may facilitate the development process of FL learning by helping them to relate their L1 to FL when the L1 is similar to the FL. In addition, the learners can provide their L1 knowledge to initiate FL utterances. It is done because they do not have sufficient acquired knowledge of the target language (Krashen, 1982).

\subsection{The Factors of Language Interference}

When people learn a foreign language, it is possible that they make a mistake in grammar. They use their native language structure into the FL. On the other hand, the learners make an error of grammar. Such analysis occurs where structures in the first language which are different from those in the foreign language produce the errors reflecting the structure of first language. Such errors were said to be due to the influence of learners' first language habits on foreign language production (Dulay et al., 1982, p. 97). When you are calling someone's name in Japanese, you have to put san after his/her name, e.g. Ayu-san.However, the Indonesian are used to calling someone only by his/her name $A y u$. In another case, the sounds of phonemes $/ \mathrm{o} /, \mathrm{n} / \mathrm{and} / \mathrm{u} / \mathrm{in}$ Japanese are different from those in Indonesian. When an Indonesian monolingual speaker reads Japanese words with such sounds, it would be different compare to the Japanese language learners. This could be involved when the Japanese learners speak their L1 caused by the different sound produced between Indonesian and Japanese.

When the learners learn the FL that has different structure, it influences on learners' L1 (Keckes, 2003). In other words, the learners who get accustomed to speaking in the FL structure, they will 
bring that habit to their L1.Laufer (2003) provides an example when the L1 speaker of English used Hebrew as L2 for a long time may say we don't have any evidences [before a phrase signifies that it is ungrammatical in native speech]. The grammatical feature 'non-count' of evidence has apparently been replaced by the 'count' feature of the Hebrew translation equivalent of evidence. Even though, FL effects on the other areas of lexical competence are not so obvious, a learner whose FL is becoming dominant may begin to experience some difficulties with retrieving L1 words for use.

\section{Research Methodology}

The subjects of this qualitative study were five Japanese advanced learners who resided in Banda Aceh. There were no special provisions to be the subjects as long as the subjects can speak Japanese as their foreign language and their first language is Indonesian. The subjects were late bilinguals because they started learning the foreign language between the age 15 - 30 years old. Two instruments were used in this study: interview guide and observation sheet. The interview is called qualitative interview meaning it is flexible, able to ask any questions, and prepared by using open-ended questions (Yin, 2011). The subjects were interviewed once at a time separately and the questions were in Indonesian. Observation was done several times in about two months with the subjects. The observation used blank paper (see Coles \& McGrath, 2015) to write down all the situation happened while observing the use of Japanese language in learners' daily activities.

The data were then analyzed based on Miles, Huberman and Saldaña's (2014) approach, which are data condensation, data display, and drawing and verifying conclusions. In this process, the first step that was done in this study was writing the narratives, then, focusing only on the utterances that were affected by FL. By reducing something which is not necessary, it may shorten the conversation based on the frameworks used. Irrelevant problem or out of the context phenomena were not taken in the study.

In the data display, assembly of information that allows conclusion drawing and action is organized and compressed (Miles, Huberman \& Saldaña, 2014). In this study, the data were presented and displayed by writing them into a narrative and underlining the words which were affected by L2based on the classification of the effects. Conclusion drawing and verifying were the third step in the analysis activity. Verification is done as a short reconsideration crossing the analyst's mind throughout writing, with a brief excursion back to the field notes (Miles, Huberman \& Saldaña, 2014).

\section{Findings and Discussions}

\subsection{The Effects of Foreign Language (FL) Learning on the Learners' L1 Use}

As explained above that FL learners could affect their L1 grammatical structures. The learners tend to use complex sentences (see Kesckes \& Papp, 2000, Keckes, 2003). Then, Cook (2003) says that there are three main grammar aspects that can be influenced when someone learns a foreign language, those are: enhancing the use of the first language; harming the use of the first 
language, and being neutral to the use of the first language. Wang (2014) in his previous study also provided same finding about the grammar aspects.

In this study, it shows that the FL effects are clearly visible in the speech of the participants. In grammatical aspects, three out of five subjects showed that the use of L1 is enhanced by learning FL. They get used to speak standard language of their L1 and even use a complete structure. It is showed by the use of more standard words when they speak Indonesian. The second effect of grammatical aspects was also showed by some participants in this study. They put their FL structure into their L1 structure. Japanese is an SOV structure language, while Indonesian is an SVO structure language. The learners tend to speak by using Japanese structure into their Indonesian. The last one is neutral to the use of first language: this is showed by a participant in this study. A participant showed this aspect in this study. He can speak Japanese well and Indonesian too. His Japanese does not influence the way he speaks Indonesian.

The Japanese language learners had been affected by their foreign language grammar when they spoke in Indonesian. During the observation when they described about a short video, their Indonesian has been influenced by their foreign language. For example, when the respondents talked, it can be seen that he inserted some Japanese words ano, etto, etc., as in the excerpts below.

S2 Menurut saya ... ano belajar ... kemudian dia bersama teman - teman yang lain saling bermain ... aaa bebas, tidak ingin aaa ... apa yang diinginkan dia ... etto seekor anjing menolong ... ano kecelakaan dan karena dia menolong seekor anjing itu.

'In my opinion ... ano study ... then he with his other friends together played ... aaa free, not want $a a a . .$. what wanted by him ... etto a dog helped ... ano accident and because he helped a dog.'

This subject got used to saying ano, aaa, and etto when she was speaking Indonesian. These words do not have meaning however the Japanese people always use them in the way they speak their language.

S3 ... dari video... ee hidup lepas, bahagia.....ee mendokusaiwanne. ... ee ... eeettonee... ee yang nomor ... bukan ee kerja ... tsurai...ee tsuraiettonee sakit kali kayaknya rasanya hidup di tempat kayak gitu ... $\underline{\text { mendokusai } . . . ~ e e ~ . . . ~ w a l a u p u n ~ e e ~}$ sekolah kita hebat...kita ee setiap hari itu sibuk atau apa ee ... Gomenne ...

'... from video ...ee life is free, happy ...ee complicated ...ee...ee that's ... ee number ... not $e e$ work ... sad (hurt) .. ee it is sad (hurt) it is very hurt live in such place ... it is complicated ...ee... eventhough ee our school is great ... we ee everyday busy or what $e e . .$. i am sorry.'

Similar to S2, S3 also showed borrowing transfer by using words ee, mendokusaiwanne, eeettonee, tsurai, tsuraiettonee, and gomenne. The subject always uses some Japanese words when she is speaking Indonesian either when observing or interviewing.

S4 ... hitori eh satu orang ... etto ... etto ... 
'... a person eh one person ... that... that ...'

Borrowing transfer is also done by S4. He unconsciously said a word in Japanese thus he immediately corrected it in Indonesian.

It can be seen that S2, S3, and S4 tended to do borrowing from their FL, Japanese. Lexical borrowing or lexical transfer is one of FL learning effects that influence on learners' L1 (see Dewaele and Pavlenko, 2003; Peukert, 2015).

Another example that learning foreign language (FL) impacts the use of learners' first language (L1) is by adding a word ' $a p a$ ' while speaking Indonesian, as in an example below.

S5 ... saya melihat apa anak-anak itu seperti diberi nomor ... sehingga karena ... bagaimana sehingga saya melihat apa ... Dan terus apalagi saya melihat pertandingan sepak bola apa di sekolah ... mengikuti suatu apa aturan yang ... sehingga ... sehingga dia itu apa ... apa dan bukan nampaknya ... apa satu orang anak, juga apa ... dan sehingga ... apaaa ... apa perasaan mereka ... aa dia masih apaaa melihat seekor anjing yang melintas ... apa anjing itu kalau andai dia melintas pasti akan tertabrak kereta sehingga anakanak itu karena dia sudah lepas control dia hari ini apa berusaha untuk menyelamatkan anjing itu sehingga anjing itu selamat dan apa anak yang nyelamatkan itu seperti apa terasa puas karena telah bisa menyelamatkan anjing itu.

'... I saw what the children like that were given number ... so that because ... how so that I saw what ... and then whatsoever I saw football game what in the school ... follow a what the rules ... so that ... so that he what ... what and it is not ... what a child, also what ... and so that ... what aa... what their feeling ... aahe still what aa saw a dog that is passing by ... what that dog if only he is passing indeed he will be crushed by the train so that the children because he was not able to be controlled he that day what tried to save that dog so that that dog were saved and what the children who saved (the dog) felt satisfied because (he) saved the dog.'

Based on the narrative above, the subject always said apa 'what'. This word means nothing when he spoke Indonesian. It looked like he translated Japanese expression ano, etto, because in Indonesian apa means 'what'. This subject spoke similar to the subject the researcher explained earlier. He often used standard connection word, sehingga, and the structure more complicated than the usual structure used in daily conversation.

Accordingly, S5 showed that his L1 structures were affected by his FL. It was supported by Keckes' (2003) argument as stating that FL learners could affect their L1 structure. The learners tend to use complex sentences (see Kesckes \& Papp, 2000, Keckes, 2003).

S5 also spoke same expression apa when interviewing

S5 ...Saya lebih sering sekarang apa alur kalimat...

"... I often now what the sentence ..."

S5 ...sehingga banyak sekali apa gaya bahasa...

"... so that many what language style ..." 
In regard to the grammatical structure inference of the FL in the learners' FL, it is found that the respondents have been influenced by the Japanese language. As mentioned above that Japanese applies SOV grammatical structure; meanwhile Indonesian has SVO structure. Therefore, the respondents in study had tended to use the Japanese grammar into Indonesian when they spoke. It can be seen when a respondent said:

\section{S2 dia bersama teman-teman yang lain saling bermain 'he with other friends plays' \\ S2 dia... seekor anjing menolong "he ... a dog helps"}

In Indonesian, verb is put after subject in a sentence. Based on the sentences above, it should be dia bermain bersama teman - teman 'he plays with friends'. In this sentence, bersama teman teman is put after the subject, however in Indonesian, it is put in the end after verb as written earlier.

Cook (2003) says that there are three main grammar aspects that can be seen when someone learns a foreign language: enhancing the use of the first language; harming the use of the first language or being neutral to the use of the first language. Wang (2014) in his previous study also provided same finding about the grammar aspect. In addition, the grammar used by subject harms her L1 grammar.

Japanese sentence: karewa tomodachitachito asobimasu（かれは友達たちと遊びます。）

Indonesian sentence: dia bermain bersama teman - teman.

Another example is in the second sentence. The subject also made ungrammatical Indonesian structure. Dia ... seekor anjing menolong should be dia ... menolong seekor anjing "he helps a dog".

Lexical borrowing or lexical transfer is one of FL learning that affects on learners' L1 (see Dewaele \& Pavlenko, 2003; Peukert, 2015). In this study, the effect is shown by the participants. They added some Japanese words while they spoke Indonesian. As the learners had highly exposed to the Japanese language, it is not surprising to find that they liked to do some borrowings when they communicated. They usually put Japanese words or expressions into Bahasa Indonesia e.g. -san, ano, etto, sousou, hai, -desu. These expressions often appear when the Japanese learners speak their L1.For example, S1 always says hai'OK' when they speak Indonesian. S5 also always puts-san in the end of someone's name or -desuin the end of nouns.

$$
\begin{aligned}
& \text { OKdesu-OK } \\
& \text { Siapdesu-ready } \\
& \text { Bukandesu-not }
\end{aligned}
$$

During the interaction with one of the researchers the subject called her name by putting -san before it. He get used to speak someone's name by adding -san. Then, he creates his own word in order to translate etto/ano in Japanese by saying apa in Indonesian when he speaks Indonesian. 
The common Japanese word that the third subject says is sou-sou 'yes- yes' and the first subject often uses conjunction word sehingga 'so that' while in Indonesian it is rarely used in speaking. The highest influence found in this study is borrowing. All the subjects showed the effect when they speak Indonesian.

\subsection{Japanese Expressions}

The words etto (えつと), ano (あの), a a (ああ), ee (ええ), are often used by the learners as a pause when they speak both languages, Bahasa Indonesia and Japanese. Therefore, they switch it unconsciously. They almost always say gomenne (ごめんね) - maaf'sorry', arigatou (ありがとう) - terimakasih'thank you', and hai (はい) - ok/baiklah'OK’ when they speak Indonesian. In this study, all the subjects used those words most of the time during the interview and observation.

A respondent, S3, had been accustomed to using sou-sou, the short form of soudesu/soudesukaoh yaya'yes'. She always said sou-souwhen she responded questions asked in Indonesian. She also used other Japanese expressions when she spoke in Indonesian, such as mendokusai (めんどくさい) - repot 'complicated', tsurai (つらい) - sakit/sedih'sad/hurt', gomenne (ごめんね) - maaf sorry’, arigatou (ありがとう) - terimakasih'thank you' hai (はい) - ok/baiklah'OK'S4, other respondent, had also been heard of saying hitori (一人) - sendiri/satu orang'a person/by myself rather than using Indonesian term itself.

It appears that FL influence on L1 use prompted foreign language to build emotions linguistically as states. In some cases, the learners realized that they were not using the appropriate frames and, as seen in the narratives and in some of the examples above.

The study finding showed that borrowing is the main effect caused by learners in studying FL. This also stated by Pavlenko (2003) that she finds Russian L2 users of English are internalizing new concepts is evident in instances of lexical borrowing (see also Haugen, 1953; Otheguy\& Garcia, 1988, 1993; Boyd, 1993; Andrews, 1993, 1999; Li, 2001; Jarvis, 2003).

Another effect found in this study is on grammatical. The FL learners affect their L1 grammar (Kecskes, 2008). Learning FL do not only involve the learning process that is depended on the context where the language is learned, but also come up with a grammar of the FL (Gass, 1990). When FL learners speak their L1, they use complicated structure in a sentence both in choosing proper word and arranging sentence. There are three aspects that FL influences the use of L1: enhance it, harm it and neutral. All aspects are showed by all subjects.

Kecskes (1995), for example, conducted an experiment with Japanese learners of English to investigate the acquisition of verbs of speech(e.g., talk, speak, tell, say, discuss) and verbs of perception (e.g., see, watch, notice, observe, perceive). This example showed that the result of experiment done presented the effect of FL into L1 which the learners were difficult to choose their L1 (Japanese) words to express their thought. It showed not only the lexical effect but only the pragmatic that differ the words. Similar to Kecskes, it was also found in the present study that the subjects showed the effect by doing switching or mixing and even translate the Japanese 
word into Indonesian to be sounded similar to Japanese. It is sometimes difficult for them to choose L1 word so that they use complicated words and structure.

The grammatical errors found in this study showed that some participants put verb in the end of a sentence. It shows their Japanese has influenced the way they arrange the sentence in speaking Indonesian. It is also determined how often they do borrowing transfer of Japanese into Indonesian. Laufer (2003, p. 21) says that the FL learners whose FL use is more often spoken then their L1 are hard to regain L1 words when they speak Indonesian.

In addition, the use of Japanese language element in this study is naturally spoken while the learners speak their L1. They add some Japanese expressions, such as, ano, etto and Japanese words, such as, gomenasai- sorry/I am sorry, arigatou- thank you.

\subsection{Foreign Language Learning Enhances the Use of First Language}

It was also found that the use of participants' L1 is enhanced by learning FL. They tend to use standard structure even make it into a complicated sentence structure. From the five Japanese leaners it can be seen that three subjects speak their standard language, while others speak more casual by using their L1.The data obtained from a language informant shows that he has proven to gain standard Indonesian grammatical sentences. For example:

S2 Menurut saya, dari video yang telah saya lihat itu merupakan video tentang seorang anak yang pergi sekolah mengikuti kegiatan sekolah seperti biasa...

'based on my opinion, from the video that I watched is a video about a child going to school and doing the activity as usual...'

S2 ... ada satu seorang anak yang selalu membuat dia penasaran pada satu hal di mana setiap yang dia kerjakan itu akan mendapatkan satu hasil yang seimbang'.

'... there is a child who always make him curious in a thing which his working will get draw score'.

The participant used standard Indonesian even though she also used some Japanese expression while speaking in her L1. However, the choice of words when she spoke L1 sounded complicated. It can be seen from the sentences above, she used very standard Indonesian. Another example can be seen as follows:

S1 sehingga anak - anak muda ...sehingga mereka tidak dalam kebebasan, tidak bisa bermain - main lagi bersama temannya kemudian bahkan...

'so that the children ... so that they are not free, cannot play together with their friends then even ...'

The sentences are correct when we speak standard Indonesian, however, in daily conversation, tidak 'no, not' is often spoken enggak or gak. The word sehingga is also very rare used in daily speaking of Bahasa Indonesia. The Indonesian speakers usually say makanya. Even the word is sometimes used in sentences but not in the order of the sentences. 
In addition, in daily use of Bahasa Indonesia, the speakers do not usually use prefix. For example, mendapatkan nilai yang bagus 'got the best score', rather it is usually spoken dapat nilai yang bagus.

\subsection{Foreign Language Learning is Neutral to the Use of First Language}

From five participants, only one participant whose Indonesian show neutral, even though he also use some Japanese expression while speaking Indonesian. When the researcher interviewed him, the researcher did not see that Japanese harm or enhance his Indonesian. He speaks Indonesian as usual and changes into Japanese style when he speak Japanese.

Q: How long have you been studying Japanese?

A: Saya belajar bahasa Jepang baru tahun lalu karena rencanya mau kerja di sana.

'I’ve learn Japanese since last year because I want to work in Japan.'

Q: Which one do you prefer, speaking in Indonesian or Japanese when you meet your friends who learn the same language?

A: Saya lebih suka pake bahasa Jepang kalau sama teman yang bisa bahasa Jepang biar cepat bisa.

'I prefer to speak Japanese with my friends who also learn Japanese so that I can my fluency in speaking.'

All questions were answered by a respondent by using good Indonesian grammar. He did not show the effects as many as other subjects did. However, he showed some of borrowing transfer while the observation was done.

\section{Conclusion}

Two FL effects were found in this study, grammatical aspects and borrowing. In grammatical aspects, three out of five subjects showed that the use of $\mathrm{L} 1$ is enhanced by learning FL.

Borrowing transfer is the most widely found in this study. All participants did borrowing especially Japanese expression such as; etto (えつと), ano (あの), a a (ああ), ee (ええ) and lexical itemsused in their speaking of L1. Some of common lexical items used by the participants in this study are arigatou (ありがとう) - thank you, gomennasai (ごめんなさい) - sorry,-desu, -san.

It can be concluded that in this study, the FL's effect found by the researcher is the learners mostly did borrowing when they speak Indonesian. Another effect is grammatical aspect that influences the structure of the learners' L1. They tend to use complicated structure and standard language and also add new word in order to translate Japanese expression, such as apa. A subject even changed the way he speak Indonesian into Japanese. When he speaks Indonesian, it sounds like he speaks Japanese, the words stressing and the intonation in Indonesian are influenced by Japanese language. The learners did borrowing and used complicated structure. 


\section{References}

Andrews, D.R. (1993) American-immigrant Russian: Socio-cultural perspectives on borrowings from English in the language of the third wave. Language Quarterly 31 (3-4), pp. 153-176.

Andrews, D.R. (1999). Sociocultural Perspectives on Language Change in Diaspora: Soviet Immigrants in the United States. Philadelphia: John BenjaminsPublishing Company.

Ary, D., Jacobs, L.C., Sorensen, C. \& Walker, D.A. (2014).Introduction to Research in Education ( $9^{\text {th }}$ ed.). Belmont: Wadsworth Cengage Learning.

Batibo, H.M. (2005). Language Decline and Death in Africa: Causes, Consequences, and Challenges. Clevedon: Multilingual Matters Ltd.

Bialystok, E. (1991). Language Processing in Bilingual Children.Cambridge: Cambridge University Press.

Bialystok, E. (2001). Bilingualism in Development: Language, Literacy and Cognition. Cambridge: Cambridge University Press.

Bloomfield, L. (1983). An Introduction to the Study of Language.Philadelphia: John Benjamins Publishing Company.

Bournot-Trites, M. \&Tallowitz, U. (2002).Report of Current Research on the Effects of Second Language Learning on First Language Literacy Skills. Halifax: The Printing House (THP).

Boyd, S. (1993) Attrition or expansion?Changes in the lexicon of Finnish and American adult bilinguals in Sweden.In K. Hyltenstam\& A. Viberg (Eds).Progression and Regression in Language: Sociocultural, Neuropsychological and Linguistic Perspectives (pp. 386-411). Cambridge: Cambridge University Press.

Braunmüller, K. \& House, J. (2009).Convergent and Divergent in Language Context Situation.Philadelphia: John Benjamins Publishing Company.

Callies, M. (2015).Effects of cross-linguistic influence in word formation: A comparative learnercorpus study of advanced interlanguage production. In Peukert, $\mathrm{H}$ (Eds).Transfer Effects in Multilingual Language Development. Philadelphia: John Benjamins Publishing Company.

Cenoz, J. (2003). The intercultural style hypothesis: L1 and L2 interaction inrequestingbehaviour. In Cook, $\mathrm{V}$ (Eds).Effect of the Second Language on the First.Clevedon: Multilingual Matters Ltd.

Chomsky, N. (2000). New Horizon The Study of Language and Mind. Cambridge: Cambridge University Press.

Clark, E.V. (2003). First Language Acquisition.Cambridge: Cambridge University Press.

Coles, A. \& McGrath, J. (2015). Your Education Master Companion: The Essential Guide to Success. London and New York: Routledge.

Cook, V. (2003). Effects of the Second Language on the First.Clevedon: Multilingual matters Ltd.

Corder, S.P. (1981).Error Analysis and Interlanguage.Oxford: Oxford University Press.

Corder, S.P. (1993).A Role of Mother Tongue. In Gass, S. M and Slinker, L (Eds). Language Transfer in Language Learning.Philadelphia: John Benjamins Publishing Company.

Cruz-Ferreira, M. (2011).First Language Acquisition and Teaching.In Wilton, A and Stegu, M (Eds).AILA Review: Applied Folk Linguistics. Philadelphia: John Benjamins Publishing Company. 
Dewaele, J.M. \& Pavlenko, A. (2003). Productivity and Lexical Diversity in Native and NonNative Speech: A Study of Cross-cultural Effects. In Cook, V (Eds).Effect of the Second Language on the First.Clevedon: Multilingual Matters Ltd.

Dulay, H., Burt, M. \&Krashen, S. (1982). Language Two. New York: Oxford University Press.

East, M. (2016).Assessing Foreign Language Student's Spoken Proficiency: Stakeholder Perspective on Assessment Innovation.Singapore: Springer Science+Business Media.

Ellis, R. (1997). Second Language Acquisition.Oxford: Oxford University Press.

Flege, J. (1987). The production of 'new' and 'similar' phones in a foreign language:evidence for the effect of equivalence classification. Journal of Phonetics 15, pp. 47-65.

Flohr, S. \&Paesler, P. (2010).Teaching Listening and Speaking.München: Grin Verlag GmbH.

Gass, S. (1990). Second language and foreign language learning: Same, different or none of the above? In B. VanPatten\& J. F. Lee (Eds.), Second language acquisition/foreign language learning.Clevedon: Multilingual Matters.

Gass, S.M. \&Selinker, L. (2001). Second Language Acquisition: An Introductory Course (2 $2^{\text {sd }}$ Ed.). Mahwah: Lawrence Erlbaum Associates, Inc.

Gera, D.L. (2003). Ancient Greek Ideas on Speech, Language, and Civilization.Oxford: Oxford University Press.

Grauberg, W. (1997).The Elements of Foreign Language Teaching ( $7^{\text {th }}$ Ed.).Clevedon: Multilingual Matters Ltd.

Hakuta, K. (1993). Second-Language Acquisition, Bilingual Education, and Prospects for a Language-Rich Nation.Restructuring Learning.1990 Summer Institute Paper and Recommendation by the Council State School Officer.

Harada, T. (2003).L2 Influence on L1 Speech in the Production of VOT. ICPhS15, pp. 1085 1088.

Harley, B., Allen, P., Cummins, J. \& Swain, M. (1990).The Development of Second Language Proficiency. Cambridge: Cambridge University Press.

Haugen, E. (1953). The Norwegian Language in America: A Study in Bilingual Behavior. Philadelphia, PA: University of Pennsylvania Press.

Ingram, D. (1988). First Language Acquisition. Cambridge: Cambridge University Press.

Jarvis, S. (2003). Probing the Effects of the L2 on the L1; A Case Study.In Cook, V (Eds).Effect of the Second Language on the First.Clevedon: Multilingual Matters Ltd.

Kamermans, M. (2010).An Introduction to Japanese: Syntax, Grammar and Language. Rotterdam: SJGR Publishing.

Kaushanskaya, M., Yoo, J. \& Marian, V. (2011).The Effect of Second Language Experience on Native Language Processing. Vigo International Journal of Applied Linguistics, 8, pp. 54-77.

Kecskes, I. (1995). Concept formation of Japanese EFL/ESL students. In M. Ahmed, T. Fujimura, Y. Kato, \& M. Leong (Eds.), Second language research in Japan (pp. 130149). Yamatomatchi: International University of Japan.

Kecskes, I. (2003). Situation-Bound Utterances in L1 and L2.In Jordens, P (Eds).Studies in Language Acquisition 19. Berlin: Mouton de Gruyter.

Kecskes, I. (2008). The Effect of the Second Language on the First Language.Sprachverlust eineSchatternseite der Mehsprachigkeit?, N2, pp. 31-34. 
Kecskes, I and Papp, T. (2000).Foreign Language and Mother Tongue.Mahwah: Lawrence Erlbaum Associates, Inc.

Krashen, D.K. (1982). Principles and Practice in Second Language Acquisition. Oxford: Pergamon Press.

Laufer, B. (2003). The Influence of L2 on L1 Collocational Knowledge and on L1 Lexical Diversity in Free Written Expression.In Cook, V (Eds).Effect of the Second Language on the First.Clevedon: Multilingual Matters Ltd.

Li, D. (2001). L2 lexis in L1: Reluctance to translate out of concern for referential meaning. Multilingua.20 (1), pp. 1-26.

Lightbown, P.M. \&Spada, N. (2013).How Languages are Learned (4 ${ }^{\text {th }}$ Ed.). Oxford: Oxford University Press

Littlewood, W.T. (1984). Foreign and Second Language Learning: Language-acquisition Research and Its Implications for the Classroom, Cambridge: Cambridge University Press.

Lott, D. (1983). Analysing and Counteracting Interference Errors.ELT Journal, 27(3), pp. 256261.

Miles, M.B., Muberman, A. \&Saldaña, J. (2014).Qualitative Data Analysis: A Methods Sourcebook ( $3^{\text {rd }}$ Ed). Los Angeles: SAGE Publications Ltd.

Montrul, S.A. (2008). Incomplete Acquisition in Bilingualism: Re-examining the Age Factor. Amsterdam/Philadelphia: John Benjamins Publishing Company.

Moyer, A. (2004). Age, Accent, and Experience in Second Language Acquisition: An Integrated Approach to Critical Period Inquiry. Clevedon: Multilingual Matters Ltd.

Murphy, V.A. \& Pine, K.J. (2003).L2 Influence on L1 Linguistic Representation.In Cook, V (Eds).Effect of the Second Language on the First.Clevedon: Multilingual Matters Ltd.

Noor, H. H. (2007). The Influence of L2 on the Syntactic Processing of L1 by Arab EFL Learners.Literature, Language and Linguistics, 1, pp. 1-18.

Ochs, E. 1979.Transcription as theory.In Ochs, E. \& B. B. Schiefflin (Eds).Developmental pragmatics (pp. 43 - 72). New York: Academic Press.

Odlin, T. (1989).Language Transfer: Cross-Linguistic Influence in Language Learning. Cambridge: Cambridge University Press.

Odlin, T. (2013).Cross-Linguistic Influence (CLI).In Byram, $\mathrm{M}$ and $\mathrm{Hu}, \mathrm{A}$. Routledge Encyclopedia of language Teaching and Learning ( $2^{\text {sd }}$ Ed.). New York: Routledge Taylor and Francis Group.

Otheguy, R. \& Garcia, O. (1988) Diffusion of lexical innovations in the Spanish of Cuban Americans. In J.L Ornstein-Galicia, G.K. Green and D. Bixler-Marquez (Eds) Research Issues and Problems in US Spanish: Latin American and Southwestern Varieties (pp. 203242). Brownsville: University of Texas.

Otheguy, R. \& Garcia, O. (1993).Convergent conceptualisations as predictors of degree of contact in US Spanish. In A. Roca and J. Lipski (Eds) Spanish in the US: Linguistic Contact and Diversity (pp. 135-154). Berlin: Mouton de Gruyter.

Pavlenko, A. (2000). L2 Influence on L1 in Late Billingualism.Issues in Applied Linguistis, 11, pp. 176-205. 
Pavlenko, A. (2003). 'I Feel Clumsy Speaking Russian': L2 Influence on L1 in Narratives of Russian L2 Users of English. In Cook, V (Eds).Effect of the Second Language on the First.Clevedon: Multilingual Matters Ltd.

Peukert, H. (2015). Transfer Effects in Multilingual Language Development. Philadelphia: John Benjamins Publishing Company.

Potowski, K. (2013). Language Maintenance and Shift.I n Bayley, R, Cameron, R, and Lucas, C (Eds).The Oxford Handbook of Sociolinguistics.Oxford: Oxford University Press.

Ringbom, H. (1987).The Role of the First Language in Foreign Language Learning.Clevedon: Multilingual Matters.

Wang, X. (2014). Effect of the Second Language on the First: A Study of ESL Students in China. Theory and Practice in Language Studies, 4, pp. 725-729.

Weinreich, U. (1968). Languages in Contact: Finding and Problems. The Hague: Mouton Publishers.

Yelland, G.W., Pollard, J. \&Mercuri, A. (1993).The metalinguistic benefits of limited contact with a second language.Applied Psycholinguistics, 14, pp. 423-444.

Yin, R.K. (2011). Qualitative Research from Start to Finish. New York: The Guilford Press. 